\title{
Differentiated Leadership and Group Performance: The Mediating Effect of Group Cohesion
}

\author{
Yu-Chuan Tung ${ }^{1}$, Yi-Ping Lin ${ }^{2} \&$ Wen-Hsin Chang ${ }^{3}$ \\ ${ }^{1}$ Department of Human Resource Development, National Kaohsiung University of Sciences and Technology, \\ Taiwan, R.O.C. \\ ${ }^{2}$ Department of Logistics Management, National Kaohsiung University of Sciences and Technology, Taiwan, \\ R.O.C. \\ ${ }^{3}$ Department of Purchasing, Yuan's General Hospital, Taiwan, R.O.C. \\ Correspondence: Yu-Chuan Tung, Department of Human Resource Development, National Kaohsiung \\ University of Sciences and Technology, 415 Chien Kung Road, Kaohsiung 807, Taiwan, R.O.C. E-mail: \\ panela@nkust.edu.tw
}

Received: November 20, 2018

Accepted: December 15, 2018

Online Published: December 18, 2018

doi:10.5539/ijbm.v14n1p114

\begin{abstract}
The aims of this study are to enhance the effectiveness of group-level differentiated leadership, and to explore the effects of Chinese differentiated leadership on group performance, and how social cohesion mediates the relationship between differentiated leadership and group performance. This study investigated 51 work groups from different enterprises in Taiwan, consisting of 51 supervisors and 230 employees. The results showed that differentiated leadership was positively associated with group social cohesion. Group social cohesion was positively associated with group performance. Finally, social cohesion fully mediated the positive relationship between differentiated leadership and group performance.
\end{abstract}

Keywords: differentiated leadership, group cohesion, social cohesion, task cohesion, group performance

\section{Introduction}

Traditionally, Chinese leaders have tended to divide employees into trusted subordinates, in-group subordinates, and out-group subordinates. These three types of employees are subject to differential treatment, access to resources, and leadership styles (Hu, Hsu, and Cheng, 2004). In addition, in recent years, research on leadership in the West has started to shift from discussion of leadership based on equality to differentiated leadership (Boies and Howell, 2006). Many studies have used vertical dyad linkage theory to discuss the quality of relations between leaders and subordinates. When leaders and subordinates maintain good leader-member exchange (LMX) relations, leaders are able to achieve effective leadership (Hui, Law, and Chen, 1999). These studies are mostly focused on the individual level rather than on groups (van Breukeln, Knost, and Van der Vlist, 2002; Erdogan and Bauer, 2010; Chen, Yu, and Son, 2014). However, the most important aspect of leadership is its ability to achieve group objectives. At the same time, due to limited resources and energy, it is not possible for leaders to maintain good relations with all of their subordinates (Brass, 1995). Leaders must make choices. However, whether the use of differentiated leadership produces positive or negative effects on groups requires further investigation (Sparrowe and Liden, 1997).

In recent years, studies on differentiated leadership have generally looked at the issue from the perspective of equality, arguing that differentiated leadership causes group members to perceive unfairness - producing negative impacts - including differentiated identification which undermines group effectiveness (Wu, Tsui, \& Kinicki, 2010) and increases conflict (Hooper and Martin, 2008); lower job satisfaction and organizational commitment which increases turnover intention (Chen et al., 2014); and undermining the positive relationship between leadership quality and the commitment of subordinates (van Breukelen et al., 2002). However, some scholars have looked at the issue from the perspective of situational leadership theory, arguing that the adoption of differentiated leadership within groups by supervisors may actually deliver positive outcomes. When leaders can identify which subordinates to develop high-quality relations with, and which subordinates to develop low-quality relations with, this can contribute to group performance in a positive way (Liden, Erdogan, Wayne, 
and Sparrowe, 2006). The present study argues that differentiated leadership has long existed in Chinese society. We expect that this type of leadership helps leaders achieve group objectives and maximize group performance. Therefore, the present study investigates whether differentiated leadership has a positive effect on groups.

In contrast to previous studies that adopt dispersion models to measure differentiated leadership, this study employs the referent-shift consensus model for measurement. Specifically, studies on differentiated leadership typically first measure leaders' leadership behaviors toward individual employees, and then calculate differences among the individual leadership behaviors in a group. In the present study, group members' shared perception of whether their leader exhibits differentiated leadership behavior in the group is measured. Group members' shared perception influences their behavior in the group and their interactions with other members. If the ratings of a leader's leadership behavior toward individual employees are used to recalculate the differentiation within the group, the differentiation may be influenced by the rating bias of individual employees, e.g. leniency error, central tendency, strictness error. Thus, the differences cannot reflect the real difference between leadership behaviors. Moreover, measurements of individual members' behaviors and attitudes then use addition or other calculation methods cannot fully represent a group (Li, Shang, Liu, Xi, 2014). Shared perception influences group members' attitudes and behaviors in the group and can effectively reflect the group dynamics (Choi, 2009). Group members' perception has a stronger influence on the interaction between the members than actual leadership behavior does (Harrison \& Klein, 2007). Differentiated leadership behavior is a group-level concept. Group members' consensus on whether the leader exhibits differentiated leadership behaviors can reflect the influence of differentiated leadership behaviors on the group.

There have been few studies looking at the direct impacts of differentiated leadership on group performance (Liden et al., 2006; Wu et al., 2010). Therefore, it is worth examining if other moderating or mediating variables influence the relationship between differentiated leadership and group performance. In the past, many scholars examined under what situations differentiated leadership increases or inhibits group performance. However, when discussing the moderating effects of average LMX, climate of fairness in organization, and task dependency (Liden et al., 2006; Henderson, Wayne, Shore, Bommer, \& Tetrick, 2008), few scholars have taken a mediating perspective to examine the relationship between group identification generated by differentiated leadership and its effect on group performance (Wu et al., 2010). Previous studies suggest that in addition to the direct effects of differentiated leadership, it is necessary to examine the influence of differentiated leadership on the process of groups (Sparrowe \& Liden, 1997), and how this in turn influences group performance (Wu et al., 2010). Differential treatment by leaders may affect relations between group members, and have an impact on group cohesion (Sparrow \& Liden, 1997). Group cohesion is an important aspect of managing groups (Wendt, Euwema, \& Van Emmerik, 2009), and is an important and frequently used mediating variable in research on teams (Mathieu, Maynard, Rapp, \& Gilson, 2008). Therefore, the present study examines the mediating role of group cohesion in the relationship between differentiated leadership and group performance to help us understand the relationship between the processes and outcomes of differentiated leadership.

\section{Theory and Hypotheses}

\subsection{Differentiated Leadership}

Chinese leaders typically apply differential treatment to their subordinates. In-group subordinates are given preferential treatment. This preferential treatment is reflected in the differences in care and communication, rewards and promotions, and trust and tolerance shown to in-group subordinates. This leadership style is known as differentiated leadership (Jiang \& Chang, 2010; Hu et al., 2004). Differences in care and communication refer to leaders providing greater care for and communication with in-group subordinates, as well as more opportunities to participate in decision making. Differences in rewards and promotions refer to differences in the allocation of resources such as rewards, promotion, or training opportunities between individuals. In-group subordinates have more opportunities for promotion and training, and have greater access to resources. Differences in rust and tolerance refer to greater trust shown to in-group subordinates who take key roles within the organization, becoming difficult to replace. In addition, the leader takes a more tolerant attitude to their mistakes at work (Jiang \& Chang, 2010). Differentiated leadership can be regarded as a group-level construct, because it explains the different relationships between leaders and subordinates within a group (Ma \& $\mathrm{Qu}, 2010$ ).

\subsection{Theoretical Background and Hypotheses}

Early studies on leadership mostly adopted the average leadership approach, assuming that leaders would treat each member of the group equally (Boies \& Howell, 2006). However, more recent studies have argued that differentiated leadership exists not only in Chinese society (Chen et al., 2014; Hu et al., 2004), but also in Western society (van Breukelen et al., 2002; Wu et al., 2010). The differentiated treatment of subordinates by 
supervisors may be based on situational theory or differences in relationships (LMX) (Wu et al., 2010). LMX theory argues that leaders will differentiate between in-group and out-group members based on their relationships with each member, and provide different levels of resources and support to in-group and out-group members (Uhl-Bien, Graen, \& Scandura, 2000). Situational leadership theory argues that leaders will adopt different leadership behaviours based on the different abilities of employees, or on their different resources and task requirements (van Breukelen et al., 2002). Therefore, the differentiated leadership behavior of supervisors toward their subordinates is likely to have a positive impact.

In Chinese society, leaders will divide subordinates into in-group and out-group subordinates according to the relationship between leaders and subordinates, contribution, and loyalty, adopting different treatment for in-group and out-group subordinates (Hu et al., 2004). In contrast to universalistic values, Chinese society stresses particularism based on the belief that people are not all treated equally. Instead, some people will be given favorable treatment according based particularistic relations (Trompenarrs, 1994). Chinese society stresses that interactions between individuals are based on the type of relationship they share and their social status. Therefore, in Chinese society, differential treatment is widely accepted (Chen et al., 2014). In contrast, leaders who adopt universalistic values will have less LMX differentiation (Ma \& Qu, 2010).

\subsection{Differentiated Leadership and Group Cohesion}

Carron, Brawley, and Widmeyer (1998) define cohesion as unity between group members to pursue instrumental objectives and/or satisfy the affective needs of members. Carron, Widmeyer, and Brawley (1985) argue that group cohesion is a multifaceted concept, including both task cohesion and social cohesion. This view has been accepted by most scholars (Cota, Evans, Dion, Kilik, \& Longman, 1995). Task cohesion is the motivation to attain the group's goal (Heuze, Sarrazin, Massiero, Raimbault, \& Thomas, 2006), commitment to the group in order to obtain group objectives (Zaccaro \& Lowe, 1988), while social cohesion in motivated by the development of members of the group and the maintenance of social relations (Heuze et al., 2006). The leadership behavior of leaders should deliver group performance. Group cohesion is an important indicator of group effectiveness. Therefore, group cohesion is an important aspect of group management (Wendt et al., 2009).

Liden et al. (2006) argue that LMX differentiation is strong associated with group cohesion, group conflict, and group potency. Highly differentiated leadership does not necessarily have a negative impact on group process. It is argued that as long as leaders can clearly establish which subordinates to develop high-quality relationships with, it is possible to improve the performance of the team (Boise and Howell, 2006). Boise and Howell (2006) found that LMX differentiation can reduce group conflicts and increase the collective belief of team members that they can successfully complete the group's various tasks. A high degree of LMX differentiation makes group members willing to invest in group tasks, providing motivation for achieving group objectives. Therefore, according to situational leadership theory, leadership that distinguishes between in-group and out-group employees, allocating tasks and distributing necessary resources according to employees' ability and motivation ensures that each group member can take tasks appropriate to their own competencies, making group members willing to invest in group tasks, achieving group goals, while also increasing collective belief among group members that they can successfully complete group goals. Therefore, the present study proposes the following hypothesis:

\section{H1a: Differentiated leadership positively relates to task cohesion.}

In groups with high LMX differentiation, employees that enjoy high LMX with supervisors will develop supportive, loyal, and high-trust relationships with supervisors, using social interaction and emotional contagion to pass on emotional commitment to other group members, increasing the overall emotional commitment of the group (Le Blanc and Gonzalez-Roma, 2012). Members with high emotional commitment are motivated to establish and develop relationships with group members (Allen and Meyer, 1990). In addition, in situations with high differentiation, employees who have low LMX with supervisors hope to develop good relations with leaders. Leaders will not maintain low LMX with all of their subordinates. Therefore, employees with low LMX will seek to use better performance to improve their LMX with leaders (Liden et al., 2006). Furthermore, supervisors will provide different guidance and tasks to employees based on employees' abilities, so each group member performs their duties in accordance with their abilities (Liden et al., 2006), reducing the occurrence of social loafing, and ensuring members of the group do not pursue different objectives, and are willing to spend time to develop relationships with other group members, thus contributing to social cohesion (Shiue, Chiu, \& Chang, 2010). On this basis, we propose the following hypothesis:

\section{H1b: Differentiated leadership positively relates to social cohesion.}




\subsection{Mediating Effects of Group Cohesion}

Scholars have argued that leadership is an important factor in increasing group performance (Kozlowski, Gully, Salas, and Cannon-Bowers, 1996). The leader has a decisive influence on group process, and ultimately on individual work performance and the performance of the group (Kahai, Sosik, \& Avolio, 1997).

However, in the past, research findings on the influence of differentiated leadership on group performance have not been consistent. Wu et al. (2010) believe that differentiated leadership that provide more coaching, more solutions to problems, as well as more opportunities to take on challenges to certain employees, meaning that group members will form different views on leaders, and therefore dividing individuals into in-group and out-group members. As a result, group members will form different levels of identification with leaders, reducing group performance. Their study does not look at the direct effects of differentiated leadership on group performance, but instead looks at the indirect effects on group performance through identification with leaders. Therefore, differentiated leadership may affect group performance only through mediating variables.

Liden et al. (2006) argue that in the case of high differentiation, employees who have low LMX with supervisors hope to develop good relations with leaders. Leaders will not maintain low LMX with all of their subordinates. Therefore, employees with low LMX seek to use better performance to improve their LMX with leaders. Role theory argues that group performance can be improved when individuals have differentiated roles. High LMX employees play central roles, performing challenging tasks. In contrast, low LMX employees are responsible for the implementation of routine tasks. If a group has individuals responsible for the implementation of each of task, it will be able to effectively reach group objectives, increasing group performance (Liden et al., 2006). From the perspective of resource use, leaders have limited time and resources. If leaders provide different levels of leadership to members of the group based on ability, enabling higher ability members to fully play to their strengths while weaker members also make their own contribution, this can deliver enhanced group performance (Liden et al., 2006).

The literature above show that differentiation may not directly affect group performance, but also affects group performance through certain mediating variables or under certain situation. The leadership behavior of leaders should enhance group effectiveness. An important indicator of group effectiveness is group cohesion (Wendt et al., 2009). Many studies have demonstrated that group cohesion increases group performance (Evans and Dion, 2012). Through leadership provided by leaders, group members will work together toward common objectives, increasing the performance of the group (Podsakoff, MacKenzie, \& Ahearne, 1997). We argued that the positive relationships between differentiated leadership and group performance are through the higher social and task cohesion that differentiated leadership is likely to bring about.

Past studies have argued that groups with high cohesion will work on their own initiative to achieve objectives, increasing group performance through participation in various group activities (Cartwright \& Zander, 1968). Group cohesion reflects the extent to which group members like other members as well as stick together to pursuit task goal attained and satisfactory relationship (Carron et al., 1998). Through bonding, members are motivated to increase their own performance and better coordinate their actions in order to achieve group objectives, increasing overall performance (Beal, Cohen, Burke, \& McLendon, 2003).

From the perspective of resource allocation, differentiated leadership enables leaders to make appropriate use of resources, distributing work in accordance with the attributes and abilities of each employee in order to complete organizational tasks. Leaders do not have the time to maintain high-quality relationships with all employees (Brass, 1995). As long as leaders can clearly establish which subordinates to develop high-quality relationships with, it is possible to improve the performance of the group (Boise \& Howell, 2006). Liden et al. (2006) argues that group members may hope that leaders treat each member of the group differently. As each member's contribution to the group is different, if leaders give each of their subordinates equal treatment, subordinates will perceive this to be unfair. In addition, leaders may adopt differential treatment in order to produce better employee performance. Leaders assign work according to ability, giving more challenging tasks to abler employees and less challenging tasks to less able employees. As a result, employees will perform better than under the non-discriminatory assignment of work. Therefore, differentiated leadership may have a positive influence on the overall performance of individuals and groups.

Looking at differentiated leadership and group cohesion, if it is not the case that all group members are willing to work hard, the distribution of challenging tasks among group members may bring pressure due to a lack of motivation or insufficient ability of group members. Erdogan and Bauer (2010) propose that differential relationships between leaders and subordinates may be based on differential contributions. Differential treatment may be accepted and welcomed. Since employees have different contributions, loyalty, and affect (Erdogan \& 
Bauer, 2010), regardless of whether leaders carry out differential allocation of tasks according the ability or contribution of employees, group members will generate a perception of fairness and of satisfaction of their individual needs. Furthermore, when members are clear about their status and position within the group (Liden et al., 2006), role satisfaction is increased, reducing the occurrence of social loafing (Høigaard, Fuglestad, Peters, Cuyper, Backer, \& Boen 2010), while increasing employees' motivation to work hard on tasks (Eys \& Carron, 2001), commitment to group goals (Mulvey \& Klein, 1998), and willingness to make an emotional investment in the group and strive to develop relations (Shiue et al., 2010), thereby increasing group performance. Therefore, this study proposes the following hypotheses:

\section{H2a: Task cohesion mediates the positive relationships between differentiated leadership and group performance.}

H2b: Social cohesion mediates the positive relationships between differentiated leadership and group performance.

\section{Methods}

\subsection{Sample and Procedures}

The initial sample for the current study was composed of 70 work groups with 330 group members from organizations from a range of industries (including health care, construction, insurance, semiconductors, metal fabrication, and private employment agencies). These groups included marketing, sales, production, R \& D, finance, human resource, and MIS departments. Research indicated that the diverse group and organizational context enhance the generalizability of our findings (Wu et al., 2010). Groups with response rates of less than $80 \%$ were excluded from this study (Sparrowe, Liden, Wayne, \& Kraimer, 2001). Our data was collected by postal distribution of questionnaires, using human resource supervisors or functional supervisors to help distribute questionnaires to their employees. Snowballing sampling was used to contact the subjects, which was useful in Chinese society (Easterby-Smith \& Malina, 1999). We collected different variables from different sources to reduce common method bias. Group members supplied data on differentiated leadership and group cohesion, and group leaders provided information on group performance. All participants were provided with a questionnaire and a return envelope to ensure that participation was anonymous and confidential.

The final sample of 230 members and 51 leaders in 51 groups had an average of 5.51 people in each group; groups ranged from 4 to 9 members, consisting a response rate of 69.70 percent for group members and 72.86 percent for groups. Among group leaders, 68.6 percent were section managers, 47.1 percent were 31-40 years of age, 35.3 percent had 4-9 years' tenure in their current department, and 39.2 percent had a $4-9$ years' organizational tenure. Among subordinates, 53.5 percent were $25-35$ years old, $42.5 \%$ were specialists and engineers, 33.9 percent had 1-3 years' tenure in their current department, and 31.3 percent had 1-3 years' organizational tenure.

\subsection{Measurement}

\subsubsection{Differentiated Leadership}

The present study used a differentiated leadership scale developed by Jiang and Chang (2010), including three main dimensions of leadership behavior: differences in care and communication (a sample item is "granting more authority"); differences in trust and tolerance (a sample item is "turning a blind eye to subordinates' mistakes"); and differences in rewards and promotions (a sample item is "takes the initiative to provide or reserve opportunities for promotion"). There were a total of 30 question items measured on a 6-point Likert scale ranging from 1 (strongly disagree) to 6 (strongly agree). We asked respondents to use their work group as a referent. Work group was defined as the group of people who all report to the same supervisor (Cogliser and Schriesheim, 2000). Before the scale, the following guidance was provided: "In the workplace,each supervisor has his/her own leadership style.In addition, some supervisors will distinguish between in-group and out-group members.In the following items, we describe possible behaviors by supervisors. Please select the most appropriate response based on actual experiences of interaction time with your immediate supervisor." Before question items, the following wording was used: "When compared to out-group subordinates, your supervisor's treatment of in-group subordinates..."

\subsubsection{Group Cohesion}

The present study used a scale of group-level cohesion developed by Chang and Bodia (2001). This scale divided cohesion into task cohesion and social cohesion. A sample item for task cohesion subscale is "our group is united in trying to reach its performance goal"; a sample item for social cohesion subscale is "our group members would rather go out on their own than work as a group". Responses were measured on a 7-point Likert 
scale, with 1 representing "strongly disagree" and 7 representing "strongly agree."

\subsubsection{Group Performance}

The present study used the scale developed by Edmondson (1999), applying a 7-point Likert scale, with 1 representing "strongly disagree" and 7 representing "strongly agree." This scale was assessed by the group leader to avoid common method variance.

\subsubsection{Control Variables}

Past studies have shown that group size is an important factor affecting group dynamics and group performance (Brewer and Kramer, 1986). Previous studies have also shown that LMX differentiation influences group attitudes and performance (Liden et al. 2006). Therefore, the present study included group size and variance in levels of in-group members as a control variable.

\subsection{Level of Analysis and Aggregation}

Before aggregating the individual responses to the group level, we calculated inter-rater agreement using two indices. First, we assessed within-group agreement by means of the Rwg index (James, Demaree, and Wolf, 1993). Then we estimated the between-group variability by computing the intra-class correlation coefficient ICC(1) (Bliese, 2000). The average Rwg for task cohesion and social cohesion were 0.92 (range from 0.74 to 0.99 ) and 0.90 (range from 0.75 to 0.99 ); the average $\mathrm{R}_{\mathrm{wg}}$ for difference in care and communication, difference in reward and promotion, and difference in trust and tolerance are 0.95 (range from 0.77 to 0.99 ), 0.94 (range from 0.77 to 0.99 ), 0.89 (range from 0.70 to 0.98 ). These figures showed adequate agreement among group members. The ICC(1) values for task cohesion and social cohesion were 0.18 and 0.15 respectively. The ICC(1) values for difference in care and communication, difference in reward and promotions, and difference in trust and tolerance were $0.18,0.28$ and 0.25 , respectively. Given these statistics, we aggregated three subscales of differentiated leadership, task and social cohesion scores up to the group level.

\section{Results}

Since group-level data were difficult to obtain, there were only 51 valid sample groups in the present study. For small data sets, the most appropriate method is partial least squares (PLS) (Hair, Sarstedt, Ringle, \& Mena, 2012). Therefore, the present study used PLS to test each of the hypotheses. Means, standard deviations, and intercorrelations of all study variables are depicted in Table 1.

Table 1. Descriptive statistics for the study variables $(n=51)$

\begin{tabular}{|c|c|c|c|c|c|c|c|}
\hline & Mean & SD & 1 & 2 & 3 & 4 & 5 \\
\hline 1. Size & 5.47 & 1.14 & 1 & & & & \\
\hline $\begin{array}{l}\text { 2.Variance in levels of in-group } \\
\text { members }\end{array}$ & 0.24 & 0.06 & 0.13 & & & & \\
\hline 3. Differentiated leadership & 3.94 & 0.42 & $0.367 * *$ & 0.037 & & & \\
\hline 4. Task cohesion & 5.56 & 0.48 & -0.018 & 0.033 & 0.01 & & \\
\hline 5. Social cohesion & 4.66 & 0.54 & 0.228 & -0.042 & $0.35^{*}$ & 0.24 & \\
\hline 6. Group performance & 5.23 & 0.96 & $0.325 *$ & 0.075 & 0.24 & -0.06 & $0.37 * *$ \\
\hline
\end{tabular}

$$
*: \mathrm{p}<0.05 * *: \mathrm{p}<0.01 \text {. }
$$

Table 2. Construct reliability and validity

\begin{tabular}{llll}
\hline Construct & Composite Reliability & Cronbach's Alpha AVE \\
\hline Differentiated leadership & 0.896 & 0.843 & 0.743 \\
Social cohesion & 0.840 & 0.720 & 0.636 \\
Task cohesion & 0.767 & 0.815 & 0.555 \\
Group performance & 0.866 & 0.799 & 0.621 \\
\hline
\end{tabular}


Table 3. Discriminant validity results using AVE approach

Differentiated leadership Social cohesion Task cohesion Group performance

Differentiated leadership (0.862)

\begin{tabular}{lllll} 
Social cohesion & 0.418 & $(0.797)$ & & \\
Task cohesion & -0.186 & -0.004 & $(0.745)$ & \\
Group performance & 0.195 & 0.394 & -0.103 & $(0.788)$ \\
\hline
\end{tabular}

Note. Square root of AVE are shown in parentheses on the diagonal.

\subsection{Measurement Model}

For scale validity, we measured composite reliability, Cronbach's alpha, and average variance extracted (AVE). As Table 2 shows, the composite reliability for differentiated leadership, social cohesion, task cohesion, and performance were between 0.767-0.896, while Cronbach's alpha were between 0.720-0.843, satisfying the standard of at least 0.7 (Nunnally, 1967). AVE was also between 0.555-0.743, greater than the 0.5 standard (Fornell \& Lacker, 1981). Based on the above, the variables in the present study had convergent validity. For discriminant validity, the square root of the AVE for the construct was higher than its correlation with other constructs, demonstrating discriminant validity (Fornell \& Lacker, 1981).

\subsection{Structural Model Analyses}

Figure 1 presents the results of the full structural model. As expected, differentiated leadership was positively related to social cohesion $(\beta=0.418, p<0.001)$, supporting Hypothesis $1 \mathrm{~b}$. However the positive relationship between differentiated leadership and task cohesion (Hypothesis 1a) is not supported $(\beta=-0.186, p=0.484)$. Hypothesis $2 \mathrm{~b}$ posited that social cohesion mediated the relationship between differentiated leadership and group performance. As we describe above, differentiated leadership had a significant positive influence on the mediator social cohesion. Next, social cohesion was positively related to group performance $(\beta=0.327, p<0.05)$. We used the Sobel test to test the mediation effect as recommended by Preacher and Hayes (2004). The result showed $z=1.95$, which implied a moderate mediating effect. We also conducted alternative modeling to test the partial mediating effect of social cohesion. We added a path from differentiated leadership to group performance (Figure $2)$. The result showed that the relationship between differentiated leadership and group performance was not significant $(\beta=-0.054, p=0.761)$. Taken together, these results showed that social cohesion fully mediates the relationship between differentiated leadership and group performance, thus supporting H2b. However, task cohesion had no significant positive relationship with performance $(\beta=-0.073, p=0.683)$, thus it failed to mediate the relationship between differentiated leadership and group performance. Hypothesis $2 \mathrm{a}$ is not supported.

We also conducted the blindfolding procedure to evaluate the predictive relevance. Blindfolding procedure was used to evaluate inner model parameter estimates (Hair et al., 2012). As figure 1 indicates, the model fitted the data well, accounting for $23.6 \%$ and $17.5 \%$ of the variance in performance and social cohesion respectively. The cross validated redundancy $\mathrm{Q}^{2}$ for social cohesion and performance were 0.092 and 0.093 , respectively, which were higher than zero, suggesting an acceptable predictive relevance and stable model estimates (Chin, 2010) 


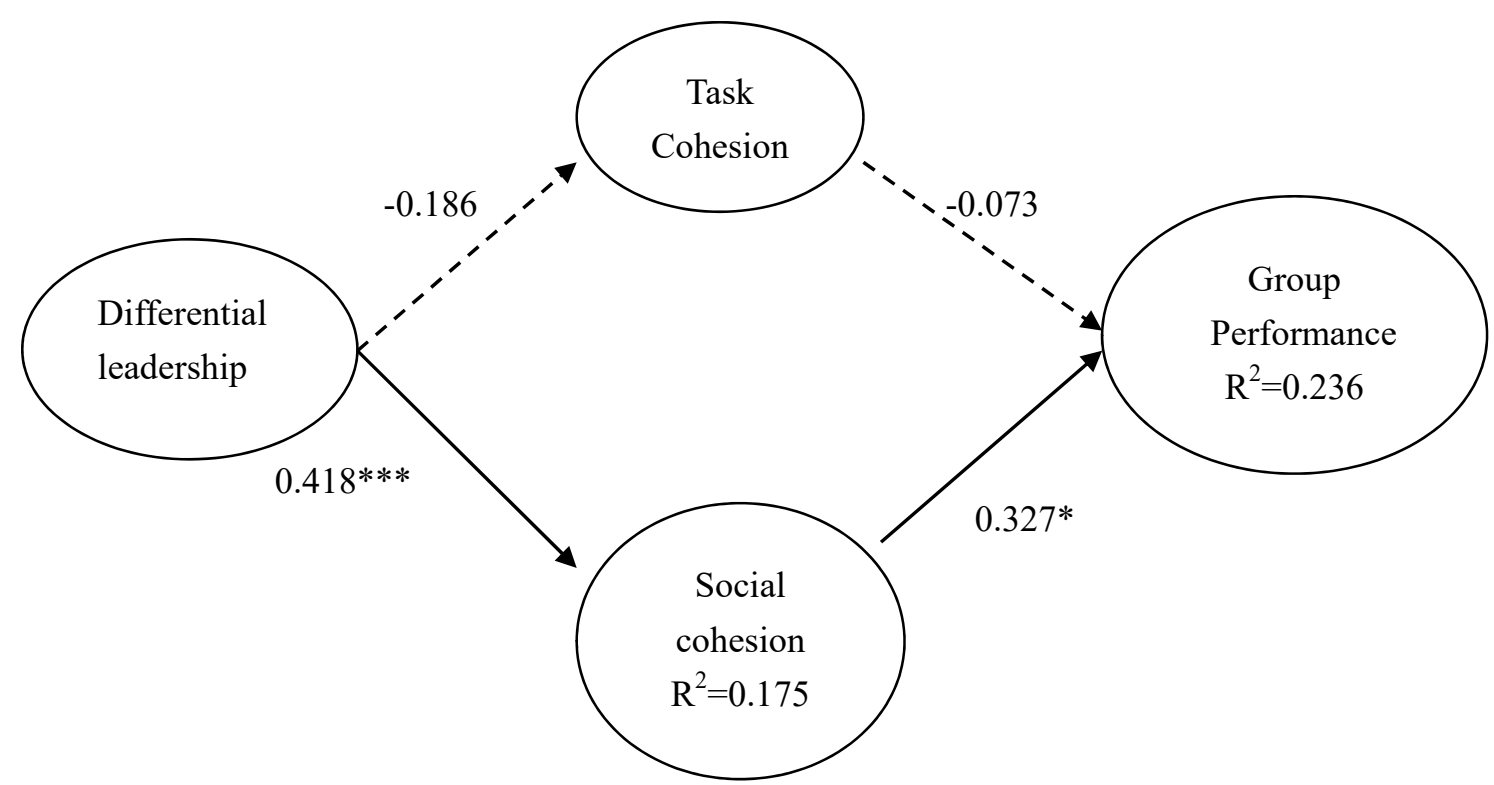

Figure 1. Results of the SEM model path coefficients

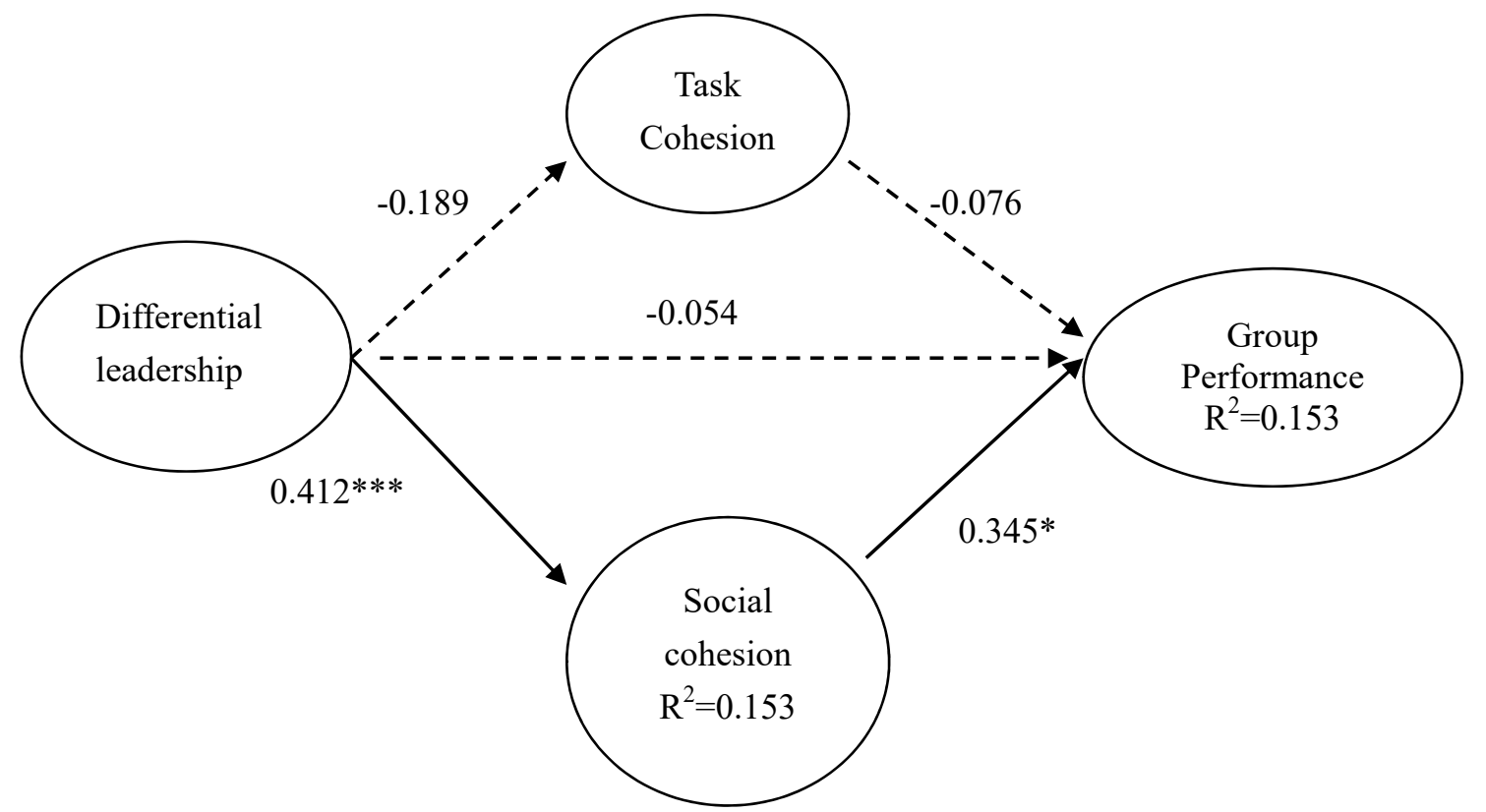

Figure 2 Results of Alternative Structural Path Coefficients

$*: \mathrm{p}<0.05^{* *}: \mathrm{p}<0.01 * * *: \mathrm{p}<0.001$.

\section{Discussion}

The present study examined the relationships between differentiated leadership and group performance, and looked at mediating effects of group cohesion variable on the relationships between differentiated leadership and group performance. The results of the research showed that differentiated leadership is beneficial to the social cohesion of groups, and that social cohesion also helps improve group performance. Furthermore, social cohesion fully mediates the relationship between differentiated leadership and group performance.

\subsection{Theoretical Implications}

First, the present study shows that differentiated leadership may produce beneficial effects on group process. The study shows that when subordinates perceive that supervisors provide differential treatment in the areas of care and communication, rewards and promotions, and tolerance of mistakes, this will have positive impacts on the social cohesion of groups. From a situational perspective, under differentiated leadership, leaders categorize employees, and provide differential treatment to in-group and out-group employees. This means that in-group 
subordinates have a sense of gratitude, and are therefore willing to put more in, work harder, and support their supervisors. Through interaction with co-workers, they will also spread this positive attitude through the group, increasing the emotional commitment of the entire group (Le Blanc and Gonzalez-Roma, 2012). Under differentiated leadership, leaders allocate work according to the professional abilities of members, giving major responsibility and core positions to in-group subordinates with high contribution, loyalty, and affect, while out-group subordinates are given responsibility for the implementation of routine tasks, allowing out-group subordinates to understand their own role and position. When out-group members believe there is an opportunity to change their situation, they will actively seek self-advancement and positive change, showing sincerity, and developing relationships and work performance in order to become a part of the supervisor's in-group (Liden et al., 2006). In terms of incentives, subordinates perceive the differential leadership behavior of the supervisors, incentivizing in-group subordinates to make greater efforts, while also incentivizing out-group subordinates to make positive changes. This can drive positive competition as well as mutual cooperation and learning between group members, increasing the social cohesion of groups. At the same time, according to role theory, members of groups carry out different tasks according to their own abilities, reducing the occurrence of social loafing and producing a harmonious atmosphere in groups. Group members share common objectives, and are willing to spend time developing relations with other group members, helping to promote social cohesion (Shiue et al., 2010).

In addition, the present study finds full mediating effects of social cohesion. The positive impacts of differentiated leadership on group performance must pass through social cohesion. This means that group leaders give in-group and out-group subordinates different levels of guidance, different task assignments, and different levels of care, increasing the job satisfaction of able and motivated subordinates, and reducing the pressure on less able subordinates. Groups are incentivized and perform better through the influence of personal interaction between group members and emotional cohesion. At the same time, members are able to effectively coordinate their work, achieving more satisfactory performance.

Furthermore, when leaders adopt differentiated leadership behaviors in a group, members who receive less leadership behavior may envy those who receive more; that is, when others are more excellent than themselves, have higher achievements, or possess resources, envy is generated (Parrott \& Smith, 1993). However, envy not only involves negative components but also positive ones. Studies have divided envy into two types: malicious envy and benign envy (Smith \& Kim, 2007). The difference between the two lies in the existence of hostility. Studies have reported that half of American respondents and one-third of Spanish respondents have experienced benign envy, indicating that benign envy does exist and accounts for a certain proportion of people's envy emotions. Benign envy is a relatively positive type of envy and can increase people's motivation to improve themselves and catch up with their peers. People with benign envy admire and express respect to those who are more outstanding than them and wish to be close to them (van de Ven, Zeelenberg, \& Pieters, 2009). Therefore, when they perceive that other group members receive more resources from the leader, they will be motivated to improve, learn from these members, and respect them. This brings a harmonious atmosphere to the group and increases the overall capability of the group, which in turn enhances the group's performance (Choi, 2009).

The mediating effect of task cohesion was not supported in the present study. This finding was different from the positive relationship between task cohesion and group performance found in previous studies (Chang, Duck, \& Bordia, 2006). Task cohesion refers to commitment by all members of the group working together to complete a specific task or objective. In the present study, sample groups were not specified as groups working together to complete certain tasks. Typically, R \& D groups are more likely to work together to complete certain tasks. This type of group only makes up a minority of groups in the present study. Therefore, it is possible that the insufficient number of sample groups with common tasks can explain why task cohesion did not produce a significant mediating effect in the relationship between task cohesion and differentiated leadership.

The present study shows that group cohesion has a mediating effect in the relationship between differentiated leadership and group performance. In previous studies, the direct relationship between differentiated leadership and group performance was not verified (Wu et al., 2010).Although past studies investigated the effects of many moderating variables (Boies \& Howell, 2006; Le Blanc and Gonzalez-Roma, 2012), there was a lack of discussion of mediating effects (Wu et al., 2010). The present study looks at both why and how differentiated leadership affects organizational performance. In addition, the present study looks at differentiated leadership in a non-US/UK context.

In contrast to previous studies that employ dispersion models to measure differentiated leadership, this study uses the referent-shift consensus model to determine whether a leader adopts differentiated leadership in a group. Compared with the method of calculating the variance of group leaders' differentiated leadership behaviors 
toward individual members, the method of using group members' consensus on the leader's differentiated leadership behaviors can more accurately represent the concept of differentiated leadership. The shared perception among group members can influence the dynamics of the group and further affect the group performance.The use of differentiated leadership is very common in Chinese society. The present study investigates the effect of this common leadership behaviour on group interaction and group outcomes, and finds that leadership behavior based on this type of particularism generated positive outcomes in Chinese society which is different outcomes with the research in western society (Wu et al., 2010). Finally, the present study is focused on the group level, examining whether differentiated leadership is able to effectively lead the group to achieve its objectives, rather than the effect of differentiated leadership on individual employees (Erdogan \& Bauer, 2010; Chen et al., 2014).

\subsection{Managerial Implications}

Differentiated leadership is a phenomenon in the Chinese social and cultural system. In Chinese society, an emphasis on relationships means that supervisors distinguish between in-group and out-group members, who are accordingly treated differently. When compared to out-group subordinates, differentiated leadership gives in-group subordinates more resources, more support and assistance, and more authority. Aside from greater interaction, this also allows for the passing on of experience and work guidance, increasing the group identification of in-group subordinates and enabling them to make full use of their talents and abilities. At the same time, while out-group subordinates are shown less care, they are clear about their own position within the organization, and feel competent to do their work. Within the group, no task is left undone and no one is left idle, making for a harmonious group and increasing group performance.

Teamwork is a trend in the development of business organizations. Increasing numbers of business are using teams as a strategy to reach their targets. The present study shows that differentiated leadership affects group performance through social cohesion. Differential treatment by supervisors means that high performing in-group subordinates perceive that supervisors show them care and attention, incentivizing in-group subordinates to make greater efforts. At the same time, out-group members will strive to become in-group subordinates. First, the present study suggests that group leaders can effectively utilize resources, providing individualized training and assistance depending on the qualities and abilities of members, allocating responsibilities in accordance with abilities, and ensuring the right person for the right job.As a result, group members can realize their full potential, and deliver a higher level of performance for the group. In addition, groups are led with a Chinese differentiated leadership style. If greater group performance is desired, it is necessary to seek social cohesion, producing good interaction between group members, increasing the extent to which group members like other members and the attractiveness of group members, producing greater solidarity and incentivizing members to work hard in order to deliver better performance and create high performing groups.

\subsection{Limitations}

We acknowledge several limitations of this study. Firstly, the differentiated leadership scale used in the present study is based on the scale developed by Jiang and Chang (2010). The scale has good internal consistency and reasonable reliability and validity in Chinese research. This scale uses the leadership of supervisors within the group as perceived group members, with the group as referent, rather than measuring the leadership behaviours of supervisors toward each members of the group and calculating its variation. We suggest that future studies carry out actual measurements of the different leadership behaviors toward each employee, and examine their effects on the dependent variable, or compare whether there are any differences between outcomes from direct measurements and perceptions for future research.

In addition,the present study measures group performance through subjective assessments, rather than objective measures. Although previous studies have shown a strong correlation between subjective performance assessment and objective measures, these may not be entirely interchangeable (Podsakoff \& Mackenzie, 1995). Other studies have pointed out that different indicators of group performance have different relationships with group cohesion (Beal et al., 2003). Therefore, we suggest that in the future objective indicators of group performance can be applied to investigate the different possible effects of differentiated leadership.

The differentiated leadership of supervisors is typically based on the loyalty, contribution, affect, and professional respect of subordinates. Supervisors engage in differentiated leadership according to the characteristics of their employees, producing different group process and outcomes (Liden \& Maslyn, 1998). The present study looks at leadership performance in groups, investigating the influence of differentiated leadership on performance. We did not look at which characteristics of subordinates different leadership styles are based on. It is suggested that future studies can explore the reasons behind the adoption of differentiated leadership by 
supervisors, and the effect of the adoption of differentiated leadership on group process.

Finally, our study sample is from work groups in Chinese society, in which we found that differentiated leadership produces positive social cohesion, thereby increasing group performance. This finding may not be applicable in Western society. It is suggested that future studies can look at work groups in Western society as its study sample, investigating whether differentiated leadership is beneficial for the process of work groups and delivers positive outcomes.

\section{References}

Allen, N. J., \& Meyer, J. P. (1990). The measurement and antecedents of affective, continuance and normative commitment to the organization. Journal of Occupational and Organizational Psychology, 63(1), 1-18. https://doi.org/10.1111/j.2044-8325.1990.tb00506.x

Allen, N. J., Stanely, D. J., Williams, H. M., \& Ross, S. J. (2007). Assessing the impact of nonresponse on work group diversity effects. Organizational Research Method, 10(2), 262-286. https://doi.org/10.1177/1094428106/294731

Beal, D. J., Cohen, R. R., Burke, M. J., \& McLendon, C. L. (2003). Cohesion and performance in groups: a meta-analytic clarification of construct relations. Journal of Applied Psychology, 88(6), 989-1004. https://doi.org/10.1037/0021-9010.88.6.989

Bliese, P. D. (2000). Within-group agreement, non-independence, and reliability: Implications for data aggregation and analysis. In K. J. Klein and S. W. J. Kozlowski (Eds.), Multilevel Theory, Research, and Methods in Organizations (pp.349-381). San Francisco, CA: Jossey-Bass.

Boies, K., \& Howell, J. M. (2006). Leader-member exchange in teams: An examination of the interaction between relationship differentiation and mean LMX in explaining team-level outcomes. The Leadership Quarterly, 17(3), 246-257. https://doi.org/10.1016/j.leaqua.2006.02.004

Brass, D. J. (1995). A social network perspective on human resources management. In G. R. Ferris (Eds.), Research in Personnel and Human Resources Management (Vol. 13, pp. 39-79). Greenwich, CT: JAI Press.

Brewer, M. B., \& Kramer, R. M. (1986). Choice behavior in social dilemmas: Effects of social identity, group size, and decision framing. Journal of Personality and Social Psychology, 50(3), 543-549. https://doi.org/10.1037/0022-3514.50.3.543

Carron, A. V., Brawley, L. R., \& Widmeyer, W. N. (1998). The measurement of cohesiveness in sport groups. In J. L. Duda (Eds.) Advances in Sport and Exercise Psychology Measurement, Morgantown (pp.213-226). WV: Fitness Information Technology.

Carron, A. V., Widmeyer, W. N., \& Brawley, L. R. (1985). The development of an instrument to assess cohesion in sport teams: The group environment questionnaire. Journal of Sport Psychology, 7(3), 244-266. https://doi.org/10.1123/jsp.7.3.244

Cartwright, D., \& Zander, A. (1968). Group Dynamics: Research and Theory. New York: Harper \& Row.

Chang, A., \& Bordia, P. (2001). A multidimensional approach to the group cohesion-group performance relationship. Small Group Research, 32(4), 379-405. https://doi.org/10.1177/104649640103200401

Chang, A., Duck, J., \& Bordia, P. (2006). Understanding the multidimensionality of group development. Small Group Research, 37(4), 327-350. https://doi.org/10.1177/1046496406290564

Chen, Y., Yu, E., \& Son, J. (2014). Beyond leader-member exchange (LMX) differentiation: An indigenous approach to leader-member relationship differentiation. The Leadership Quarterly, 25(3), 611-627. https://doi.org/10.1016/j.leaqua.2013.12.004

Chin, W. W. (2010). How to write up and report PLS analyses. In Handbook of partial least squares (pp. 655-690). Heidelberg, Berlin: Springer.

Choi, J. N. (2009). Collective dynamics of citizenship behaviour: What group characteristics promote grouplevel helping?. Journal of Management Studies, 46(8), 1396-1420. https://doi.org/10.1111/j.1467-6486.2009.00851.x

Cogliser, C. C., \& Schriesheim, C. A. (2000). Exploring work unit context and leader-member exchange: A multi-level perspective. Journal of Organizational Behavior, 21(5), 487-511. https://doi.org/10.1002/1099-1379(200008)21:5<487::AID-JOB57>3.0.CO;2-P 
Cota, A. A., Evans, C. R., Dion, K. L., Kilik, L., \& Longman, R. S. (1995). The structure of group cohesion. Personality and Social Psychology Bulletin, 21(6), 572-580. https://doi.org/10.1177/0146167295216003

Easterby-Smith, M., \& Malina, D. (1999). Cross-cultural collaborative research: Toward reflexivity. Academy of Management Journal, 42(1), 76-86. https://doi.org/10.5465/256875

Edmondson, A. (1999). Psychological safety and learning behavior in work teams. Administrative Science Quarterly, 44(2), 350-383. https://doi.org/10.2307/2666999

Erdogan, B., \& Bauer, T. N. (2010). Differentiated leader-member exchanges: The buffering role of justice climate. Journal of Applied Psychology, 95(6), 1104-1120. https://doi.org/10.1037/a0020578

Evans, C. R., \& Dion, K. L. (2012). Group cohesion and performance: A meta-analysis. Small Group Research, 43(6), 690-701. https://doi.org/10.1177/1046496412468074

Eys, M. A., \& Carron, A. V. (2001). Role ambiguity, task cohesion, and task self-efficacy. Small Group Research, 32(3), 356-373. https://doi.org/10.1177/104649640103200305

Fornell, C., \& Larcker, D. F. (1981). Evaluating structural equation models with unobservable variables and measurement error. Journal of Marketing Research, 18(1), 39-50. https://doi.org/10.2307/3151312

Hair, J. F., Sarstedt, M., Ringle, C. M., \& Mena, J. A. (2012). An assessment of the use of partial least squares structural equation modeling in marketing research. Journal of the Academy of Marketing Science, 40(3), 414-433. https://doi.org/10.1007/s11747-011-0261-6

Harrison, D. A., \& Klein, K. J. (2007). What's the difference? Diversity constructs as separation, variety, or disparity in organizations. Academy of Management Review, 32(4), 1199-1228. https://doi.org/10.5465/amr.2007.26586096

Henderson, D. J., Wayne, S. J., Shore, L. M., Bommer, W. H., \& Tetrick, L. E. (2008). Leader-member exchange, differentiation, and psychological contract fulfillment: A multilevel examination. Journal of Applied Psychology, 93(6), 1208-1219. https://doi.org/10.1037/a0012678

Heuzé, J. P., Sarrazin, P., Masiero, M., Raimbault, N., \& Thomas, J. P. (2006). The relationships of perceived motivational climate to cohesion and collective efficacy in elite female teams. Journal of Applied Sport Psychology, 18(3), 201-218. https://doi.org/10.1080/10413200600830273

Høigaard, R., Fuglestad, S., Peters, D. M., Cuyper, B. D., Backer, M. D., \& Boen, F. (2010). Role satisfaction mediates the relation between role ambiguity and social loafing among elite women handball players. Journal of Applied Sport Psychology, 22(4), 408-419. https://doi.org/10.1080/10413200.2010.495326

Hooper, D. T., \& Martin, R. (2008). Beyond personal leader-member exchange (LMX) quality: The effects of perceived LMX variability on employee reactions. The Leadership Quarterly, 19(1), 20-30. https://doi.org/10.1016/j.leaqua.2007.12.002

Hu, H. H., Hsu, W. L., \& Cheng, B. S. (2004). Reward allocation decisions of Chinese managers: Influence of employee categorization and allocation context. Asian Journal of Social Psychology, 7(2), 221-232. https://doi.org/10.1111/j.1467-839x.2004.00146.x

Hui, C., Law, K. S., \& Chen, Z. X. (1999). A structural equation model of the effects of negative affectivity, leader-member exchange, and perceived job mobility on in-role and extra-role performance: A Chinese case. Organizational Behavior and Human Decision Processes, 77(1), 3-21. https://doi.org/10.1006/obhd.1998.2812

James, L. R., Demaree, R. G., \& Wolf, G. (1993). rwg: An assessment of within-group interrater agreement. Journal of Applied Psychology, 78(2), 306-309. http://dx.doi.org/10.1037/0021-9010.78.2.306

Jiang, D. Y. \& Chang, W. (2010). Differentiated leadership and subordinate effectiveness in Chinese context. Indigenous Psychological Research in Chinese Societies, 33, 109-177 (in Chinese). https://doi.org/10.6254/IPRCS

Jogulu, U., \& Ferkins, L. (2012). Leadership and culture in Asia: The case of Malaysia. Asia Pacific Business Review, 18(4), 531-549. https://doi.org/10.1080/13602381.2012.690301

Jung, D. I., \& Sosik, J. J. (2002). Transformational leadership in work groups: The role of empowerment, cohesiveness, and collective-efficacy on perceived group performance. Small Group Research, 33(3), 313-336. https://doi.org/10.1177/10496402033003002 
Kahai, S. S., Sosik, J. J., \& Avolio, B. J. (1997). Effects of leadership style and problem structure on work group process and outcomes in an electronic meeting system environment. Personnel Psychology, 50(1), 121-146. https://doi.org/10.1111/j.1744-6570.1997.tb00903.x

Kozlowski, S. W., Gully, S. M., McHugh, P. P., Salas, E., \& Cannon-Bowers, J. A. (1996). A dynamic theory of leadership and team effectiveness: Developmental and task contingent leader roles. In G. R. Ferris (Eds.), Research in Personnel and Human Resources Management (Vol. 14, pp. 253-305). Greenwich, CT: JAI Press.

Le Blanc, P. M., \& González-Romá, V. (2012). A team level investigation of the relationship between Leader-Member Exchange (LMX) differentiation, and commitment and performance. The Leadership Quarterly, 23(3), 534-544. https://doi.org/10.1016/j.leaqua.2011.12.006

Li, G., Shang, Y., Liu, H., \& Xi, Y. (2014). Differentiated transformational leadership and knowledge sharing: A cross-level investigation. European Management Journal, 32(4), 554-563. https://doi.org/10.1016/j.emj.2013.10.004

Liden, R. C., \& Maslyn, J. M. (1998). Multidimensionafity of leader-member exchange: An empirical assessment through scale development. Journal of Management, 24(1), 43-72. https://doi.org/10.1177/014920639802400105

Liden, R. C., Erdogan, B., Wayne, S. J., \& Sparrowe, R. T. (2006). Leader-member exchange, differentiation, and task interdependence: Implications for individual and group performance. Journal of Organizational Behavior, 27(6), 723-746. https://doi.org/10.1002/job.409

Ma, L., \& Qu, Q. (2010). Differentiation in leader-member exchange: A hierarchical linear modeling approach. The Leadership Quarterly, 21(5), 733-744. https://doi.org/10.1016/j.leaqua.2010.07.004

Mathieu, J., Maynard, M. T., Rapp, T., \& Gilson, L. (2008). Team effectiveness 1997-2007: A review of recent advancements and a glimpse into the future. Journal of Management, 34(3), 410-476. https://doi.org/10.1177/0149206308316061

Mulvey, P. W., \& Klein, H. J. (1998). The impact of perceived loafing and collective efficacy on group goal processes and group performance. Organizational Behavior and Human Decision Processes, 74(1), 62-87. https://doi.org/10.1006/obhd.1998.2753

Nunnally, J. C., Bernstein, I. H., \& Berge, J. M. T. (1967). Psychometric Theory, New York: McGraw-Hill.

Parrott, W. G., \& Smith, R. H. (1993). Distinguishing the experiences of envy and jealousy. Journal of Personality and Social Psychology, 64(6), 906-920. http://doi.org/10.1037/0022-3514.64.6.906

Podsakoff, P. M., MacKenzie, S. B., \& Ahearne, M. (1997). Moderating effects of goal acceptance on the relationship between group cohesiveness and productivity. Journal of Applied Psychology, 82(6), 974-983. http://doi.org/10.1037/0021-9010.82.6.374

Shiue, Y. C., Chiu, C. M., \& Chang, C. C. (2010). Exploring and mitigating social loafing in online communities. Computers in Human Behavior, 26(4), 768-777. https://doi.org/10.1016/j.chb.2010.01.014

Smith, R. H., \& Kim, S. H. (2007). Comprehending envy. Psychological Bulletin, 133(1), 46-64. https://doi.org/10.1037/0033-2909.133.1.46

Sosik, J. J., Avolio, B. J., \& Kahai, S. S. (1997). Effects of leadership style and anonymity on group potency and effectiveness in a group decision support system environment. Journal of Applied Psychology, 82(1), 89-103. https://doi.org/10.1037/0021-9010.82.1.89

Sparrowe, R. T., \& Liden, R. C. (1997). Process and structure in leader-member exchange. Academy of Management Review, 22(2), 522-552. https://doi.org/10.5465/AMR.1997.9707154068

Sparrowe, R. T., Liden, R. C., Wayne, S. J., \& Kraimer, M. L. (2001). Social networks and the performance of individuals and groups. Academy of Management Journal, 44(2), 316-325. https://doi.org/10.5465/3069458

Trompenaars, F. (1994). Riding the Waves of Culture: Understanding Diversity in Global Business. Burr Ridge, IL: Irwin.

Uhl-Bien, M., Graen, G. B., \& Scandura, T. A. (2000). Implications of leader-member exchange (LMX) for strategic human resource management systems: Relationships as social capital for competitive advantage. In G. R. Ferris (Eds.), Research in Personnel and Human Resources Management (Vol. 18, pp. 137-186). Greenwich, CT: JAI Press. 
Van Breukelen, W. I. M., Konst, D., \& Van Der Vlist, R. E. N. E. (2002). Effects of LMX and differential treatment on work unit commitment. Psychological Reports, 91(1), 220-230. https://doi.org/10.2466/pr0.2002.91.1.220

Van Dijk, W. W., Ouwerkerk, J. W., Goslinga, S., Nieweg, M., \& Gallucci, M. (2006). When people fall from grace: Reconsidering the role of envy in schadenfreude. Emotion, 6(1), 156-160. http://doi.org/10.1037/1528-3542.6.1.156

Wendt, H., Euwema, M. C., \& Van Emmerik, I. H. (2009). Leadership and team cohesiveness across cultures. The Leadership Quarterly, 20(3), 358-370. https://doi.org/10.1016/j.leaqua.2009.03.005

Wu, J. B., Tsui, A. S., \& Kinicki, A. J. (2010). Consequences of differentiated leadership in groups. Academy of Management Journal, 53(1), 90-106. https://doi.org/10.5465/amj.2010.48037079

Zaccaro, S. J., \& Lowe, C. A. (1988). Cohesiveness and performance on an additive task: Evidence for multidimensionality. The Journal of Social Psychology, 128(4), 547-558. https://doi.org/10.1080/00224545.1988.9713774

\section{Copyrights}

Copyright for this article is retained by the author(s), with first publication rights granted to the journal.

This is an open-access article distributed under the terms and conditions of the Creative Commons Attribution license (http://creativecommons.org/licenses/by/4.0/). 